\title{
Microbiological Contamination and Sanitary Management of Aquarium Water in the Busan Area
}

\author{
Kyung-Soon Cho \\ Division of Virus, Busan Institute of Health and Environment, Busan 616-842, Korea
}

\begin{abstract}
This research has been performed by our own investigation, also cooperated with Health and Sanification Division and each of district offices in Busan metropolitan city. After choosing, we collected water samples five times for microbiological examination. As a result of investigating in 160 water samples from urban areas, we could detect 88 cases of Vibrio spp. Furthermore, there were four cases exceeding the acceptable limit of aquarium water $(100,00 / \mathrm{mL})$ and another four cases exceeding the limit of Coliform group $(1,000$ below $/ 100 \mathrm{~mL}$ ). As a result of investigating that we performed for 271 cases of water samples from coastal areas from April to November, we could detect 130 cases of vibrio species and 10 cases of Coliform group. After performing 17 kinds of antibiotic susceptibility test for 41 cases of isolated Vibrio parahaemolyticus, 27 cases showed tolerance to Amplicllin (AM), all of 31 cases showed intermediate resistance only to Cefazolin (CF) but had sensitivity to the rest of them. As a result of performing antibiotic susceptibility test, serum test and PFGE gene analysis on each 10 pair of Vibrio parahaemolyticus detected concurrently from intake-pipe water and, aquarium water, we couldn't get data showing that they are clearly same species in three kinds of test. In addition, UV sterilization, Ozonization and so on. Based on our research, intake pipe didn't have a problem with microbiological contamination so we are sure that the germ came from supplied fish had caused that kind of contamination. For effective management, UV sterilization or Ozonization which can be handled consistently should be adopted in aquarium.
\end{abstract}

Keywords: Aquarium water, Vibrio parahaemolyticus, PFGE, Antibiotics

This is an Open Access article distributed under the terms of the Creative Commons Attribution Non-Commercial License (http://creativecommons.org/licenses/by-nc/3.0) which permits unrestricted non-commercial use, distribution, and reproduction in any medium, provided the original work is properly cited.

Copyright @ 2014 The Korean Society for Clinical Laboratory Science. All rights reserved.
Corresponding author: Kyung-Soon Cho Division of Virus, Busan Institute of Health and Environment, Busan 616-842, Korea. Tel: 82-51-309-2810

E-mail: viruscho@korea.kr

Received: February 8, 2014 Revised: March 28, 2014 Accepted: March 28, 2014

\section{서 론}

부산은 지리적 여건상 동북아 최대의 물류 허브항인 동시에 우 리나라 최대의 어항(漁港)이다. 동남 양방향으로 바다와 접하고 있 어 예로부터 각종 해산물이 풍부하고 해산물의 생식문화가 발달하 여 그에 대한 연구도 활발히 이루어지고 있다. 하지만, 활어의 식감 을 즐기는 식습관에 따라 대부분 업소마다 수족관을 보유하고 식재 료를 공급함에 따라 수족관의 위생문제가 중요한 문제가 되고 있 다.

본 연구에서 주요 오염지표로 사용한 장염 비브리오균(Vibrio parahaemolyticus)은 비브리오科에 속하는 대표적인 해양세균으 로서 우리나라 수인성 식품매개성 감염질환 주요 원인균이며, 멀 미, 구토, 복부경련, 미열, 오한을 동반한 위장염을 나타낸다. 증상 은 보통 경미하여 수분, 전해질 균형을 유지해주는 것만으로 $1 \sim 4$
일 후에 저절로 회복된다(질병관리본부, 2005). 특히 어패류를 생 식하는 우리나라, 일본을 비롯해 대만, 태국, 라오스, 미국 등지에 서 문제시되고 있다(Matsumoto 등, 2000; 이향 등, 2007).

장염 비브리오균에 의한 감염은 대부분 증상이 심하지 않고 자 가 치유가 가능하나, 장외감염의 경우에는 수분과 전해질을 공급해 야 하며 필요에 따라 적절한 항생제로 치료해야 한다.

항생제의 오남용에 따라 세균의 내성획득으로 야기된 병원균의 항생제 내성이 큰 사회적 문제로 대두되고 있고, 특히 여러 항생제 에 대해 동시에 내성을 갖는 슈퍼박테리아의 출현으로 질병치료의 어려움과 추가적인 내성균 확산 등이 우려되고 있으며, 이러한 항 생제 내성문제는 전 세계적으로 주요한 공중보건 문제로 대두되고 있으며, 특히 병원 내 감염에서 문제가 되고 있다(질병관리본부, 2008). 감염병 전문가들은 특히 이용 가능한 항생제에 대한 저항성 을 가진 균들이 전 세계적으로 병원 내에서 분리되기 때문에 관심 
을 가지고 있으며, 항생제 남용이 더 흔한 개발도상국에서 항생제 내성 정도는 더욱 높다(Gupta 등, 2001; Hakanen 등, 2001; Isenbarger 등, 2002).

또한, 근래의 세균검사는 PFGE를 통한 역학분야에서의 병원성 세균간의 유연관계를 확인하여 원인적 연관성 추적에 중점을 두는 추세이다. 이 방법은 전기장의 각도를 다양하게 지정함으로써 큰 size의 DNA를 분리할 수 있다. 세균의 Chromosomal DNA를 제 한효소로 절단하여 전기영동을 수행한 후 나타나는 band 양 성을 비교해 봄으로써 분리균주의 유사성을 밝힐 수 있다(Ching, 2004; DeLappe 등, 2006; Kim 등, 2006; 방선재 등, 2008; 설성 용 등, 2000).

본 연구에서는 부산시내 각 구 · 군별로 두 군데의 횟집 수족관 을 지정해 그 관리주체, 관리방법, 관리주기 등을 살펴보고 수족관 수의 위생세균 오염실태를 우선 파악하며, 이와 별도로 자체 채수 가능한 대형 활어센터의 수족관 및 취수관에 대해서도 동일 항목을 조사하고 수족관수, 취수관수에서 동시에 균이 검출된 경우 분리된 균주 중 비브리오 균주의 항생제 내성양상 및 혈청형을 살펴보고, 두 균주간 분자 역학적 연관성을 PFGE시험을 통해 비교하였으며, 조사된 데이터 등을 바탕으로 가장 합리적인 수족관수 관리방안을 제시하고자 하였다.

\section{재료 및 방법}

\section{1. 연구대상}

해안지역 대형 활어유통업체 수족관수 9개소 등에 대해 4월 11월 월 2회씩 채수한 취수관수 143건, 수족관수 128건 및 부산지 역 16개구 · 군별로 각 2개의 횟집 수족관수 32개소에 대해 2011 년 총 5 차에 걸쳐 채수한 수족관수 160 건 등 총 431 건의 검체를 연

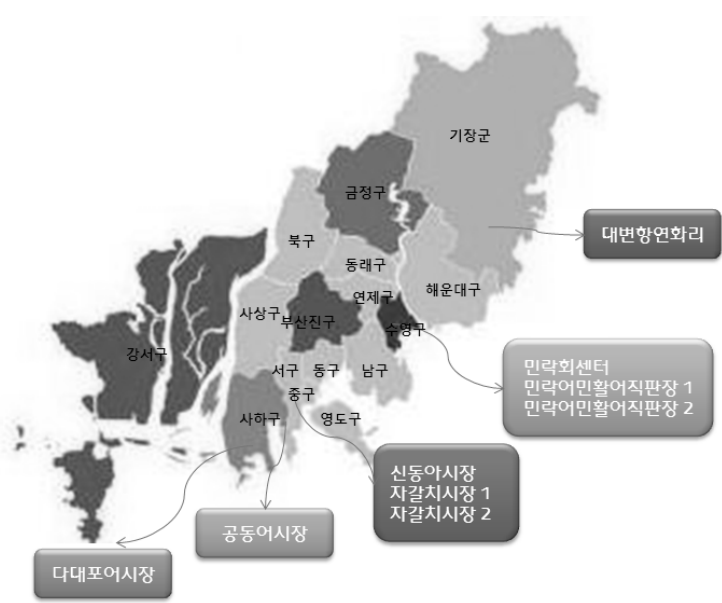

Fig. 1. The taken place of Aquarium in the Busan coastal areas.
구대상으로 하였으며, 그 채취지점은 Fig. 1, 2와 같다.

\section{2. 시험방법}

시험항목은 식품공전의 규격항목인 세균수, 대장균군과 수족관 에서 문제가 될 수 있는 비브리오균 屬, 살모넬라균 屬, 쉬겔라균 屬 등으로 선정하였다. 도심지역 횟집 수족관수의 경우 그 관리방법 및 관리주체, 주기 등을 조사하고 미생물학적 검사를 실시하여 관 리법에 따른 미생물 오염정도를 조사하고자 하였고, 해안구역 대형 활어센터의 경우에는 같은 시험항목을 취수관수 및 수족관수에 각 각 적용하여 수족관에 유입되는 취수관수와수족관수의 연관성을 파 악하고자 미생물오염도 및 분리된 비브리오균 屬중 장염비브리오에 대해 항생제 감수성 및 분자역학적 시험인 PFGE를 실시하였다.

\section{1) 미생물 시험}

시험방법은 식품공전 제 8. 식품접객업소(집단급식소 포함)의 조리식품 등에 대한 기준 및 규격 4. 규격 다) 조리기구 등 (1) 수족관 물의 (1) 세균수, (2) 대장균군에 따라 기준 규격 검사를 실시하였으 며, 비브리오 3종, 살모넬라, 세균성이질 항목은 식품공전 제 10 일 반시험 3. 미생물시험법(식품의약품안전청, 2011)에 따라 실시하 였으며, 그 구체적인 시험방법은 아래와 같다.

세균수 측정은 표준 평판법을 이용하였다. 즉, 멸균 페트리디쉬 에 단계 희석액 $1 \mathrm{~mL}$ 을 취하고 표준한천배지 약 $15 \mathrm{~mL}$ 을 분주한 후 $35 \sim 37^{\circ} \mathrm{C}$ 에서 $24 \sim 48$ 시간 배양한 후 1평판 당 30 300개의 집락을 생성한 평판을 선택하여 집락 계산기를 사용하여 집락수를 계산하여 2개 평판배지에 나타난 집락을 계수하여 평균치로 하였다.

대장균군은 최확수법에 따라 시험하였다. 즉, 검액 $10 \mathrm{~mL}, 1$ $\mathrm{mL}, 0.1 \mathrm{~mL}$ 를 각각 5 개의 Brilliant green lactose bile broth (BGLB) 배지에 접종하여 $35 \pm 1^{\circ} \mathrm{C}$ 에서 24 시간 배양한 후 가스발생

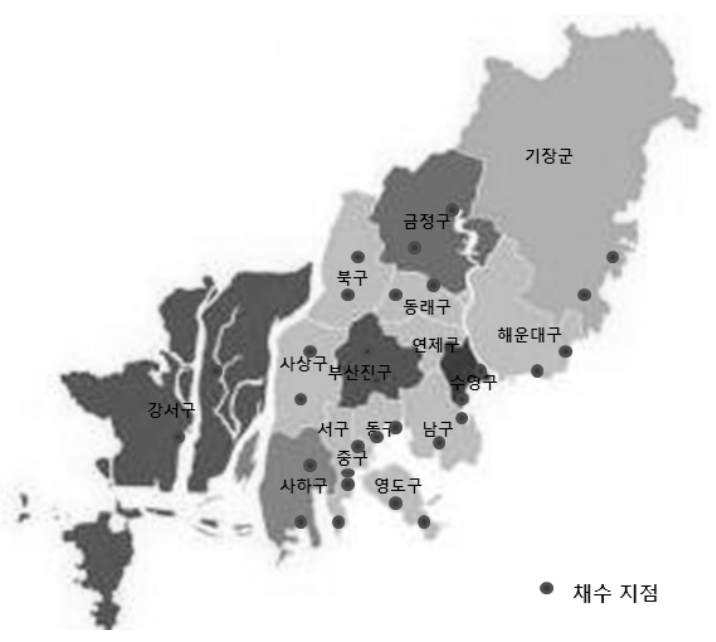

Fig. 2. The taken place of Aquarium in the Busan urban areas. 
시험관 각각에 대하여 추정, 확정, 완전 시험을 행하고 대장균군의 유무를 확인하였고, MPN/100 mL로 결과를 나타내었다.

비브리오균속(비브리오 콜레라균, 비브리오 패혈증균, 장염 비 브리오균)은 해수 $1 \mathrm{~L}$ 를 여과하여 그 여과지를 잘게 잘라 $\mathrm{APW}$ (Alkaline peptone water, $\mathrm{pH}$ 8.6, $2 \% \mathrm{NaCl}$ )에 넣고 증균 배양한 후 thiosulfate citrate bile salts sucrose agar (TCBS) 한천배지에 접종하여 분리배양 및 확인시험을 실시하고 생화학적 확인동정을 진행하였다.

살모넬라균속 및 쉬겔라균속은 해수 $1 \mathrm{~L}$ 를 여과하여 여과지를 잘게 잘라서 Selenite F Broth에 $37 \pm 2^{\circ} \mathrm{C}$ 에서 24 시간 증균 배양한 후 Salmonella-Shigella agar (SS)배지에 접종하여 분리배양 후 확 인시험을 실시하고 생화학적 확인동정을 진행하였다.

\section{2) 항생제 감수성 시험}

항생제에 대한 감수성은 식품의약품안전청에서 발간된 항생제 내성균 검사 표준 시험법 중 미생물자동화기기를 이용한 감수성 검 사법(Minimum inhibition concentration, MIC test)(한아름 등, 2012) 및 질병관리본부 국립보건연구원 발간 항균제 감수성 표준 시험법(식품의약품안전청, 2010)에 따라 실시하였다. 시험장비는 bioMerieux 사(France)의 Vitek II이며, 항생제 키트는 국립보건 연구원과 bioMerieux (France)사가 공동 개발한 AST-N169를 사 용하였고, 항생제의 종류 및 내성 판단기준은 Table 1과 같이 2008 년 CLSI의 Enterobacteriaceae 기준에 따랐다. 시험방법은 Tryptic soy agar (Difco, USA)에 접종하여 $37^{\circ} \mathrm{C}$ 에서 24시간씩 2 회 계대하여 순수 분리되었음을 확인한 후 $3 \mathrm{~mL}$ 의 $0.45 \%$ 의 saline

Table 1. Determination of susceptibility, intermediated resistance and resistance of bacteria to 17 Antibiotics by standard suggested by CLSI-MIC test

\begin{tabular}{lccl}
\hline \multicolumn{1}{c}{ Antimicrobial agents } & Suceptibility & Intermediate & Resistance \\
\hline Ampicillin (AM) & $\leq 8$ & 16 & $\geq 32$ \\
Amikacin (AN) & $\leq 16$ & 32 & $\geq 64$ \\
Ampicillin/ & $\leq 8 / 4$ & $16 / 8$ & $\geq 32 / 16$ \\
$\quad$ Sulbactam (SAM) & $\leq 8$ & 16 & $\geq 32$ \\
Cephalothin (CF) & $\leq 8$ & 16 & $\geq 32$ \\
Cefazolin (CZ) & $\leq 8$ & 16 & $\geq 32$ \\
Cefoxitin (FOX) & $\leq 16$ & 32 & $\geq 64$ \\
Cefotetan (CTT) & $\leq 8$ & $16-32$ & $\geq 64$ \\
Cefotaxime (CTX) & $\leq 1$ & 2 & $\geq 4$ \\
Ciprofloxacin (CIP) & $\leq 8$ & 16 & $\geq 32$ \\
Chloramphenicol (C) & $\leq 4$ & 8 & $\geq 16$ \\
Gentamycin (GM) & $\leq 4$ & 8 & $\geq 16$ \\
Imipenem (IPM) & $\leq 16$ & - & $\geq 32$ \\
Nalidixic acid (NA) & $\leq 4$ & 8 & $\geq 16$ \\
Tetracycline (TE) & $\leq 8$ & $16-32$ & $\geq 64$ \\
Ceftriaxone (CRO) & $\leq 2 / 38$ & - & $\geq 4 / 76$ \\
Trimethprim/ & \multicolumn{1}{c}{ Sulfamethoxazole (SXT) } & & \\
$\quad$ Amoxicillin/ & $\leq 8 / 4$ & $16 / 8$ & $\geq 32 / 16$ \\
$\quad$ Clavulanic Acid (AMC) & & & \\
\hline
\end{tabular}

에 균액을 $0.6 \mathrm{McF}$ 로 만들어 이 균현탁액 $145 \mu \mathrm{L}$ 를 취해 $3 \mathrm{~mL}$ 의 $0.45 \%$ saline에 주입하고 잘 섞은 후 이 균 현탁액을 카드 실험에 사 용하여 실험을 실시하였다. 본 실험에서는 총 17 종의 항생제에 대 해 분석이 이루어졌다.

\section{3) 혈청형 시험}

장염비브리오의 진단용 면역혈청(Denka Seiken Co., Ltd., Japan)을 사용하였으며, O항원시험은 시험균주를 3\% 멸균생리식 염수에 현탁한 후 가열 $\left(100^{\circ} \mathrm{C}, 1\right.$ 시간 또는 $121^{\circ} \mathrm{C}, 15$ 분)하여 $\mathrm{O} 1$ $\mathrm{O} 11$ 의 혈청에 대해 슬라이드글라스 응집반응을 실시하였다, $\mathrm{K}$ 항 원 시험은 시험균주를 멸균생리식염수에 현탁한 후 $\mathrm{KI} ~ \mathrm{KIX}$ 의 Poly 혈청에 대해 슬라이드글라스 응집반응을 실시 한 후, 응집되 는 균주에 대해서 $\mathrm{K}$ 항원 단가 혈청반응시험을 추가로 실시하여 응 집유무를 확인하였다.

\section{4) PFGE (Pulsed Field Gel Electrophoresis)시험}

$\mathrm{PFGE}$ 시험방법은 질병관리본부 국립보건연구원에서 발간한 PFGE (Pulsed Field Gel Electrophoresis) 표준실험법(2008), 이 승주 등(2009)의 방법에 따랐다.

\section{(1) Agarose mold의 제조}

실험균주는 Triptic Soy Agar배지에서 14 18시간 배양하여 사용하였고, molecular weight marker로는 Salmonella serovar Braenderup ATCC BAA-664를 사용하였다. 실험 시작에 앞서 멸 균된 증류수, plug wash TE (Tris-EDTA) buffer (10 mM Tris pH 7.5 and $1 \mathrm{mM} \mathrm{EDTA}, \mathrm{pH}$ 7.5)와 1.2\% plug용 agarose (Seakem Gold, USA)를 준비하여 $55^{\circ} \mathrm{C}$ 항온수조에서 보관하였다. 먼저 폴 리에틸렌 튜브 $(12 \times 75 \mathrm{~mm})$ 에 cell suspension TE (Tris-EDTA) buffer (100 mM Tris pH 7.5 and 100 mM EDTA, pH 7.5) 2 mL를 넣고 면봉으로 균을 현탁하여 Vitek 탁도계로 15 20\%의 투명도 로 조정하였다. 만들어진 균 현탁액 $200 \mu \mathrm{L}$ 를 $1.5 \mathrm{~mL}$ microcentrifuge tubes에 옮긴 다음 준비되어 있는 $1.2 \%$ plug용 agarose $\operatorname{mix} 200 \mu \mathrm{L}$ 를 tube에 넣고, micropipette으로 천천히 4회 정도 섞 은 후, 바로 plug mold (Bio-Rad, USA)에 넣었다. plug mold를 $4^{\circ} \mathrm{C}$ 에서 5 분 정도 굳히고, 이 시간을 이용하여 ES Buffer $(0.5 \mathrm{M}$ EDTA, $\mathrm{pH} 8.0$ 의 $1 \%$ sodium-lauroyl-sarcosine) $1.5 \mathrm{~mL}$ 과 proteinase $\mathrm{K} 40 \mu \mathrm{L}(20 \mathrm{mg} / \mathrm{mL})$ 를 $2 \mathrm{~mL}$ microcentrifuge tube 에 준비하였다.

\section{(2) 제한효소 처리}

응고한 plug를 꺼내서 ES buffer/pk로 옮기고 $55^{\circ} \mathrm{C}$ 진탕 항온 
수조에서 2시간 처리하였다. Plug를 번호가 표시된 screen cap (Bio-Rad)에 각 검체별로 넣고, cap을 column형태로 조립한 다 음, $\mathrm{PVC}$ 파이프로 만든 tube에 넣었다. 실험 전에 미리 $55^{\circ} \mathrm{C}$ 로 준 비해둔 멸균 증류수를 $\mathrm{PVC}$ 파이프에 넣고 $55^{\circ} \mathrm{C}$ 진탕 항온수조에 서 15 분간 plug를 세척한 후 멸균 증류수를 제거하고 미리 $55^{\circ} \mathrm{C}$ 로 준비해둔 세척용 완충용액인 plug wash TE buffer를 넣어 $55^{\circ} \mathrm{C}$ 진탕 항온수조에서 30 분 동안 5 회 처리하였다. 세척이 끝난 plug를 에탄올로 닦은 면도칼을 이용하여 $1 \mathrm{~mm}$ 두께로 자른 다음, 자른 2 개의 절편을 $1.5 \mathrm{~mL}$ microcentrifuge tube에 넣고, 남은 plug는 사용하지 않은 plug wash TE buffer가 들어있는 $2 \mathrm{~mL}$ microcentrifuge tube에 넣어 $4^{\circ} \mathrm{C}$ 에서 보관하였다. $1 \mathrm{~mm}$ 두께의 plug 절 편이 들어 있는 $1.5 \mathrm{~mL}$ microcentrifuge tube에 제한효소용 완충 용액(TaKaRa, Japan) $10 \mu \mathrm{L}$, 제한효소 Not I (NEB, $40 \mathrm{U} / \mu \mathrm{L}) 4 \mu \mathrm{L}$, $\mathrm{BSA}$ (NEB) $1 \mu \mathrm{L}$, 멸균 증류수 $85 \mu \mathrm{L}$ 를 넣고 $50^{\circ} \mathrm{C}$ 항온수조에서 4 시간 반응시켰으며, marker로 사용한 Salmonella serovar Braenderup ATCC BAA-664는 Xba I (NEB, $40 \mathrm{U} / \mu \mathrm{L}$ ) $2 \mu \mathrm{L}$, 완충 용액(TaKaRa, Japan) $10 \mu \mathrm{L}, \mathrm{BSA}$ (NEB) $1 \mu \mathrm{L}$, 멸균 증류수 $87 \mu \mathrm{L}$ 를 넣고 $37^{\circ} \mathrm{C}$ 항온수조에서 4 시간 반응하였다.

(3) 전기영동

제한효소반응이 끝나면 반응용액을 제거하고, plug 절편이 들 어있는 tube에 plug wash TE buffer를 $200 \mu \mathrm{L}$ 를 채워 넣는다. PFGE용 agarose를 사용하여 1\% agarose 용액을 gel 크기에 맞추 어 녹인 후, $55^{\circ} \mathrm{C}$ 항온수조에서 보관하고, 제한효소 처리가 끝난 plug 절편을 꺼내어서 agarose gel 성형용 comb의 끝 부위에 맞추 어 올려놓은 후 여과지로 주변의 물기를 제거하고 상온에서 10 분 정도 건조시켰다. 절편의 건조가 끝나면 comb을 설치하고, $1 \%$ agarose 용액을 gel에 붓고 gel이 굳으면 comb를 제거하였다. Comb에 의해 만들어진 well은 agarose 용액을 부어서 채웠다. Gel을 전기영동 cell에 넣어 CHEF II Mapper PFGE (Bio-Rad, $\mathrm{USA}$ )를 이용하여 gradient $6.0 \mathrm{~V} / \mathrm{cm}$, included angle $120^{\circ}$, initial time 2.16초, final time 63.8 초의 조건으로 $14^{\circ} \mathrm{C}$ 에서 18 시 간 전기영동을 하였다. 전기영동이 완료되면 $500 \mathrm{~mL}$ 의 ethidium bromide 염색용액 $(0.5 \mu \mathrm{g} / \mathrm{mL})$ 에 gel을 넣어 30 분간 염색을 하고 증류수를 이용하여 1 시간씩 2회 탈색을 하였다.

$\mathrm{PFGE}$ 결과는 각 균주의 DNA위치가 다른 절편의 수에 따라서 group을 결정하였고, BioNumerics software (Applied Maths, Belgium)를 이용하여 Dendrogram을 작성하여 균주간의 유연관 계를 비교분석하였다.

\section{결 과}

\section{1. 균주 분리현황}

\section{1) 해안지역 대형 활어유통센터 9 개소}

4 월부터 11 월까지 월 2회 총 9개소의 대형활어센터에서 취수관 및 수족관수를 조사한 결과는 아래와 같다.

취수관수 143 건에 대해 검사한 결과 비브리오균속이 73 건(비브 리오콜레라(비병원성 non O-1, non O-139) 4건, 비브리오패혈

Table 2. The Vibrio spp. from intake pipe water in coastal areas

\begin{tabular}{|c|c|c|c|c|c|c|}
\hline & \multirow{2}{*}{\multicolumn{2}{|c|}{ 검체수 }} & \multirow[b]{2}{*}{ 검출수(율) } & \multicolumn{3}{|c|}{ 검사 항목 } \\
\hline & & & & $\begin{array}{c}\text { V. cholerae } \\
\text { (non } 0-1, \text { non } 0-139 \text { ) }\end{array}$ & V. vulnificus & V. parahaemolyticus \\
\hline 계 & \multicolumn{2}{|c|}{ 143건 } & $73(51.04 \%)$ & 4 & 21 & 62 \\
\hline \multirow{2}{*}{ 4월 } & 1차 & 9건 & 1 & - & - & 1 \\
\hline & 2차 & 9건 & 2 & - & 2 & - \\
\hline \multirow{2}{*}{ 5월 } & 1차 & 9건 & $2^{*}$ & - & 1 & 2 \\
\hline & 2차 & 8건 & 1 & - & 1 & - \\
\hline \multirow{2}{*}{ 6월 } & 1차 & 9건 & 1 & - & - & 1 \\
\hline & 2차 & 9건 & 3 & - & 1 & 2 \\
\hline \multirow{2}{*}{ 7월 } & 1차 & 9건 & $6^{*}$ & 1 & - & 6 \\
\hline & 2차 & 9건 & $8^{*}$ & - & 1 & 8 \\
\hline \multirow{2}{*}{ 8월 } & 1차 & 9건 & $8^{*}$ & - & 3 & 6 \\
\hline & 2차 & 9건 & $8^{*}$ & - & 3 & 7 \\
\hline \multirow{2}{*}{ 9월 } & 1차 & 9건 & $6^{*}$ & - & 1 & 6 \\
\hline & 2차 & 9건 & $7^{*}$ & 1 & 2 & 6 \\
\hline \multirow{2}{*}{ 10월 } & 1차 & 9건 & 3 & - & 1 & 2 \\
\hline & 2차 & 9건 & $5^{*}$ & 1 & 3 & 4 \\
\hline \multirow{2}{*}{ 11월 } & 1차 & 9건 & $5^{*}$ & 1 & 1 & 4 \\
\hline & 2차 & 9건 & $7^{\star}$ & - & 1 & 7 \\
\hline
\end{tabular}

*중복 검출. 
증균 21건, 장염비브리오균 62건, 중복검출 포함) 검출되었다. 세 균수는 모두 수족관수 기준치인 100,000 이하 $/ \mathrm{mL}$ 이하였으며, 대 장균군은 6 건에서 기준치인 1,000 이하/100 mL를 초과하였다 (Table 2).

또한, 수족관수 128 건에 대해 시험한 결과 비브리오균속 57 건 (비병원성 Vibrio cholerae 3건, Vibrio vulnificus 13건, Vibrio parahaemolyticus 46건)이 검출되었으며, 세균수는 취수관수와 마찬가지로 모두 수족관수 기준치인 100,000 이하 $/ \mathrm{mL}$ 이하였으 며, 대장균군은 4 건에서 기준치인 1,000 이하/ $100 \mathrm{~mL}$ 를 초과하는 것으로 나타났다. 하지만 같은 업체 취수관 및 수족관에서 대장균 군이 동시에 기준을 초과하는 경우는 2 건이었다. 이는 비록 취수관 을 통해 오염되었다 하더라도 수족관수의 청소, 소독 등으로 식품

Table 3. The Vibrio spp. from aquarium water in coastal areas

\begin{tabular}{|c|c|c|c|c|c|c|}
\hline & \multirow{2}{*}{\multicolumn{2}{|c|}{ 검체수 }} & \multirow[b]{2}{*}{ 검출수(율) } & \multicolumn{3}{|c|}{ 검사 항목 } \\
\hline & & & & $\begin{array}{c}\text { V. cholerae } \\
\text { (non O-1, non O-139) }\end{array}$ & V. vulnificus & V. parahaemolyticus \\
\hline 계 & \multicolumn{2}{|c|}{ 128건 } & $57(44.5 \%)$ & 3 & 13 & 46 \\
\hline \multirow{2}{*}{ 4월 } & 1차 & 8건 & - & - & - & - \\
\hline & 2차 & 8건 & - & - & - & - \\
\hline \multirow{2}{*}{ 5월 } & 1차 & 8건 & 2 & - & 1 & 1 \\
\hline & 2차 & 8건 & 1 & - & 1 & - \\
\hline \multirow{2}{*}{ 6월 } & 1차 & 8건 & 3 & - & - & 3 \\
\hline & 2차 & 8건 & 3 & - & 1 & 2 \\
\hline \multirow{2}{*}{ 7월 } & 1차 & 8건 & 4 & 1 & - & 4 \\
\hline & 2차 & 8건 & $7^{\star}$ & - & 1 & 7 \\
\hline \multirow{2}{*}{ 8월 } & 1차 & 8건 & 5 & - & 1 & 4 \\
\hline & 2차 & 8건 & 7 & - & 1 & 6 \\
\hline \multirow{2}{*}{ 9월 } & 1차 & 8건 & 1 & - & - & 1 \\
\hline & 2차 & 8건 & 4 & - & 1 & 3 \\
\hline \multirow{2}{*}{ 10월 } & 1차 & 8건 & 3 & - & 1 & 2 \\
\hline & 2차 & 8건 & 5 & 1 & 2 & 2 \\
\hline \multirow{2}{*}{ 11월 } & 1차 & 8건 & $5^{*}$ & 1 & 3 & 4 \\
\hline & 2차 & 8건 & 7 & - & - & 7 \\
\hline
\end{tabular}

*중복 검출.

Table 4. Monthly distribution of Vibrio spp. from intake pipe water and aquarium water in coastal areas

\begin{tabular}{|c|c|c|c|c|c|c|c|c|c|c|}
\hline & & & & & & 채수장소 & & & & \\
\hline 채수 & & (1) 다대포 & ○ 750 . & (3) 신동아시장 & (4) 자갈치시장 & (5) 자갈치시장 & (6) 민락회센터 & (7) 민락어민 & (8) 민락어민 & (9) 대변항 \\
\hline 4월 & 1차 & & & & & & & & & \\
\hline 4펼 & 2차 & & & & & & & & & \\
\hline & 1차 & & & & & & & & & \\
\hline 5월 & 2차 & & & & & & V. vul & & & \\
\hline & 1차 & & & & V. para & & & & & \\
\hline 6월 & 2차 & & & & V. para & & V. vul & & & \\
\hline 7월 & 1차 & V. para & & & V. para & & $\begin{array}{l}\text { V. para } \\
\text { V. cho }\end{array}$ & & V. para & \\
\hline & 2차 & & & V. para & V. para & V. para & V. para & V. para & V. para & V. para \\
\hline & 1차 & & & & & & V. vul & V. para & V. para & \\
\hline 8월 & 2차 & V. para & & V. para & V. para & & & V. para & & V. para \\
\hline & 1차 & & & & & & & & V. para & \\
\hline 9월 & 2차 & & & & V. para & V. para & V. vul & V. para & & \\
\hline 10월 & 1차 & & & & & & V. para & & & \\
\hline 10펼 & 2차 & V. vul & & V. cho & V. para & & V. para & & & \\
\hline & 1차 & & & V. para & & & V. para & & & V. para \\
\hline 11월 & 2차 & V. para & & & & V. para & V. para & V. para & V. para & V. para \\
\hline
\end{tabular}

※. cho, V. cholerae (non O-1, non 0-139); V. vul, V. vulnificus; V. para, V. parahaemolyticus. 
공전 규격수준의 제균은 이루어지는 것으로 보인다. 또한, 살모넬 라와 세균성이질균은 취수관, 수족관 모두에서 검출되지 않았다 (Table 3).

조사대상 9군데 수족관의 수온은 $16 \sim 28^{\circ} \mathrm{C}$ 의 범위였고, 주로 락스 등을 이용해 월 3 4회 소독하는 것으로 조사되었다. 수족관 수와 취수관수에서 동시에 비브리오균속이 검출된 경우를 월별로 Table 4로 나타내었으며, Vibrio parahaemolyticus 36건, 비병원 성 Vibrio cholerae 2건, Vibrio vulnificus 5건 등 총 43군데의 취 수관수 및 수족관수에서 동일한 균종이 검출되었다. 이들 중 10 월 이후 열 군데의 수족관수 및 취수관수에서 동시에 분리된 Vibrio parahaemolyticus를 임의로 선정하여 항생제 감수성 및 균주의 PFGE 패턴을 분석한 결과는 뒤에 따로 기술하였다.

\section{2) 도심지역 횟집 32개소}

16 개 구 · 군에서 총 5 차에 걸쳐 채수한 160 건에 대한 검사 결과 비브리오균속 88건(비병원성 Vibrio cholerae 1건, Vibrio vulnificus 10건, Vibrio parahaemolyticus 77건, 중복검출 포함) 이 검출되었고, 세균수는 수족관수 기준치인 $100,000 / \mathrm{mL}$ 이상인 경우가 4건이었으며, 대장균군은 4건에서 기준치인 1,000이하/ $100 \mathrm{~mL}$ 를 초과하는 것으로 나타났다(Table 5).

\section{3) 수족관수 청소, 소독 관리실태}

도심지역 횟집 수족관수에 대해 조사를 실시한 32 개소에 대한 관리 실태 및 소독방법은 Table 6에 나타내었다. 조사한 수족관수 의 $\mathrm{pH}$ 범위는 $6.8 \sim 8.0$ 이었으며, 수온은 $14 \sim 20^{\circ} \mathrm{C}$ 였다.

수족관수 교체방법은 업주 직접 교체가 28 개소, 의뢰가 4 개소 등이며, 교체주기는 바닷물 직접연결로 상시 교체가 4 개소, 5 회 이 상/주 14 개소, 3 회/주 10 개소, 2 회 이하/주가 4 개소 등으로 나타났
다. 소독방법으로는 수족관수 교체 3 개소, 청소 13 개소, 정수(여과 기, 돌 등 이용) 4 개소, 염소소독 등 약품소독 10 개소, 자외선소독 1 개소, 오존 소독 1 개소 등이었으며, 모든 소독방법에도 불구하고 5 차에 걸친 검사에서 비브리오가 한 건도 검출되지 않은 경우는 없 었다.

이러한 결과는 수족관수를 소독 교체함에도 활어가 계속 공급됨 에 따라 부착되어 들어오는 세균의 오염은 피하기 어려운 이유로 보이며, 그중에서 대장균군 등 기준규격항목에서 부적합을 보이는 방법으로는 약품소독 1건, 청소 2건, 염소소독 1건 등이었다. 오존 소독, 자외선소독, 정수기 부착 등의 방법은 위의 방법들과 비교할 때 상대적으로 위생적인 방법으로 볼 수 있겠다.

\section{2. 항생제 감수성 시험결과}

\section{1) 해안지역 대형 활어센터}

분리된 균주 중 임의 선정한 Vibrio parahaemolyticus 총 28건 에 대한 17종의 항생제에 대한 감수성 시험 결과 Ampicillin (AM) Ampocillin with Sulbacctam (SAM), Cefotetan (CTT), Cefotaxime (CTX), Ciprofloxcin (CIP), Chloramphenicol (C), Gentamicin (GM), Imipenem (IPM), Nalidixic acid (NA), Tetracycline(TE), Ticarcillin (TIC), Sulfamethoxazole with Trimethoprim (SXT), Amoxicillin with Clarnlanic acid (AMC) 등 13종의 항생제에 대해서는 내성이 관찰되지 않았으며, $\mathrm{AM}$ 은 16 건이 내성, 11 건이 중간내성으로 1 건이 감수성으로 대부분의 균 이 감수성을 나타냄을 알 수 있었다. 또한 Cephalothin $(\mathrm{CF})$ 는 28 건 모두가 중간내성, Cefazolin (CZ)는 6건이 중간 내성, 12건이 감 수성을 나타내었으며, Cefoxitin (FOX)는 1건에서 중간내성을 나 타내었다. 이 해안지역 수족관수 및 취수관수에서 분리된 균주에 대한 내성은 Fig. 3과 같이 나타났다.

Table 5. The separated status of the microorganism to the aquarium water in urban areas

\begin{tabular}{|c|c|c|c|c|c|c|c|c|}
\hline \multirow{2}{*}{$\begin{array}{c}\text { 식품공전 규격 } \\
\text { (기준) }\end{array}$} & \multirow{2}{*}{$\begin{array}{c}\text { 세균수 } \\
(100,000 \text { 이하/ } \\
\mathrm{mL})\end{array}$} & \multirow{2}{*}{$\begin{array}{c}\text { 대장균군 } \\
(1,000 \text { 이하/ } \\
100 \mathrm{~mL})\end{array}$} & \multirow{2}{*}{ 구 분 } & \multicolumn{3}{|c|}{ 비브리오균속 } & \multirow{2}{*}{ 살모넬라 } & \multirow{2}{*}{$\begin{array}{r}\text { 세균성 } \\
\text { 이질 }\end{array}$} \\
\hline & & & & $\begin{array}{c}\text { 장염 } \\
\text { 비브리오균 }\end{array}$ & $\begin{array}{l}\text { 비브리오 } \\
\text { 패혈증균 }\end{array}$ & $\begin{array}{c}\text { 비병원성 } \\
\text { 비브리오 콜레라 }\end{array}$ & & \\
\hline $\begin{array}{c}\text { 부적합 건수 } \\
\text { (부적합율) }\end{array}$ & $\begin{array}{c}0 \\
(0)\end{array}$ & $\begin{array}{c}4 \\
(2.5 \%)\end{array}$ & $\begin{array}{l}\text { 검출건수 } \\
\text { (검출율) }\end{array}$ & $\begin{array}{c}70 \\
(43.8 \%)\end{array}$ & $\begin{array}{c}17 \\
(10.6 \%)\end{array}$ & $\begin{array}{c}1 \\
(0.6 \%)\end{array}$ & 0 & 0 \\
\hline
\end{tabular}

Table 6. Management survey of the aquarium water in urban areas

\begin{tabular}{|c|c|c|c|c|c|c|c|c|c|c|c|c|}
\hline \multirow[b]{2}{*}{ 구 분 } & \multicolumn{2}{|c|}{ 교체방법 } & \multicolumn{4}{|c|}{ 교체주기/주 } & \multicolumn{6}{|c|}{ 소독방법 } \\
\hline & 직접 & 의뢰 & $\begin{array}{l}5 \text { 회 } \\
\text { 이상 }\end{array}$ & 3회 & $\begin{array}{l}\text { 2회 } \\
\text { 이하 }\end{array}$ & $\begin{array}{l}\text { 상시 } \\
\text { 공급 }\end{array}$ & 청소 & 물교체 & 정수 & 약품소독 & 자외선 & 오존 \\
\hline $\begin{array}{c}\text { 업소 수 } \\
\text { (비율, \%) }\end{array}$ & $\begin{array}{c}28 \\
(87.5)\end{array}$ & $\begin{array}{c}4 \\
(12.5)\end{array}$ & $\begin{array}{c}14 \\
(43.8)\end{array}$ & $\begin{array}{c}10 \\
(31.3)\end{array}$ & $\begin{array}{c}4 \\
(12.5)\end{array}$ & $\begin{array}{c}4 \\
(12.5)\end{array}$ & $\begin{array}{c}13 \\
(40.6)\end{array}$ & $\begin{array}{c}3 \\
(9.4)\end{array}$ & $\begin{array}{c}4 \\
(12.5)\end{array}$ & $\begin{array}{c}10 \\
(31.3)\end{array}$ & $\begin{array}{c}1 \\
(3.1)\end{array}$ & $\begin{array}{c}1 \\
(3.1)\end{array}$ \\
\hline
\end{tabular}




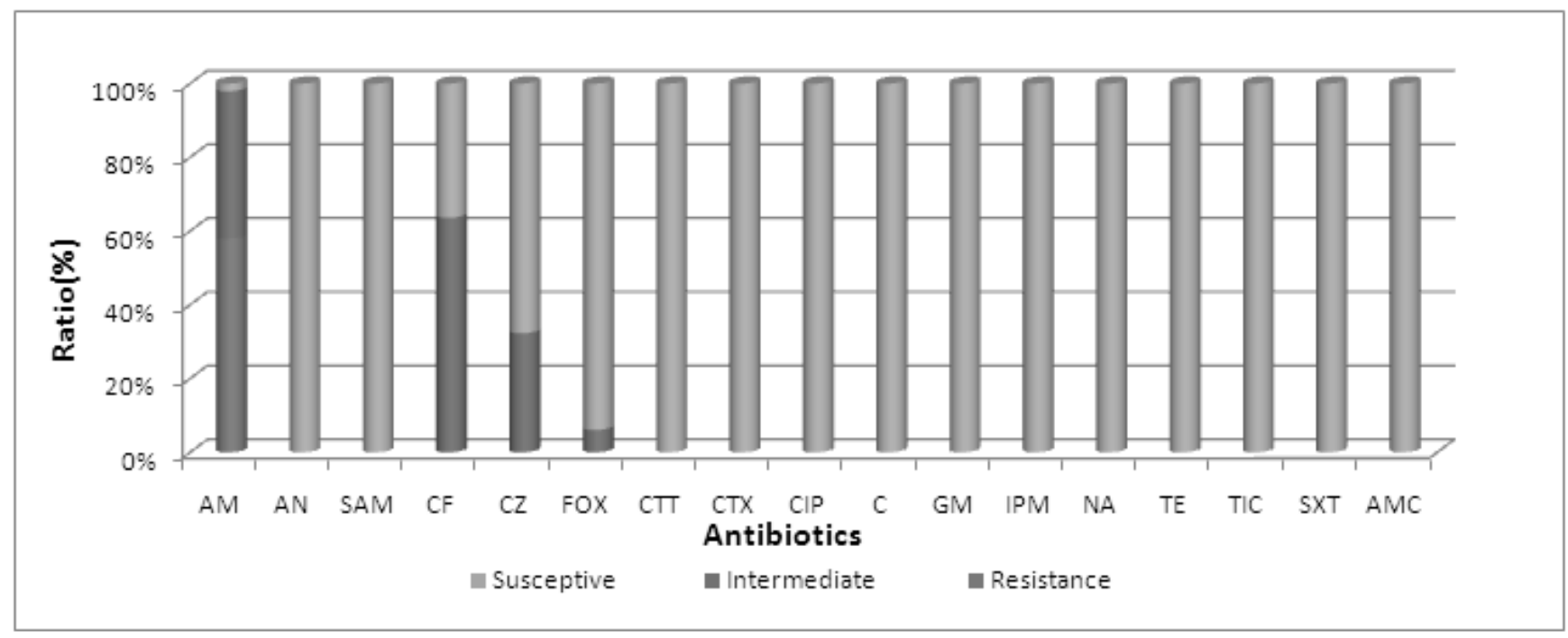

Fig. 3. Susceptibility ratio which follows in antibiotics type from live fish market in coastal areas.

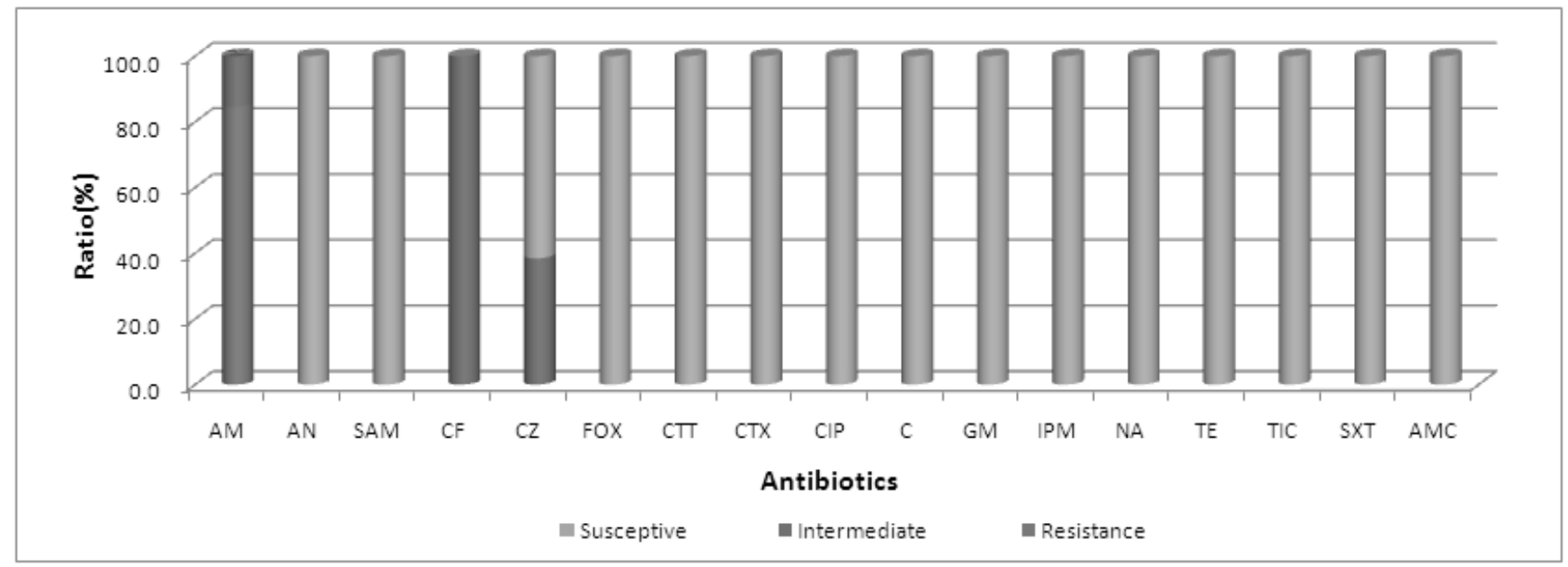

Fig. 4. Susceptibility ratio which follows in antibiotics type from aquarium water in urban areas.

Table 7. Antibiotic sensitivity comparison of the same time isolated strains in coastal areas

\begin{tabular}{|c|c|c|c|c|c|c|c|c|c|c|}
\hline 항생제내성 채수장소 & $\begin{array}{l}\text { 1.자갈치 } \\
\text { 10월 2차 }\end{array}$ & $\begin{array}{l}\text { 2.민락 } \\
\text { 10월2차 }\end{array}$ & $\begin{array}{l}\text { 3.신동아 } \\
\text { 11월1차 }\end{array}$ & $\begin{array}{l}\text { 4.민락 } \\
\text { 11월1차 }\end{array}$ & $\begin{array}{l}\text { 5.연화리 } \\
\text { 11월1차 }\end{array}$ & $\begin{array}{l}\text { 6.자갈치 } \\
\text { 11월2차 }\end{array}$ & $\begin{array}{l}\text { 7.민락 } \\
\text { 11월2차 }\end{array}$ & $\begin{array}{l}\text { 8.민락 } \\
\text { 11월2차 }\end{array}$ & $\begin{array}{l}\text { 9.민락 } \\
\text { 11월2차 }\end{array}$ & $\begin{array}{l}\text { 10.연화리 } \\
\text { 11월2차 }\end{array}$ \\
\hline-1 취수관 & $\begin{array}{l}\text { AM-I } \\
\text { CF-I }\end{array}$ & $\begin{array}{l}\text { AM-I } \\
\text { CF-I }\end{array}$ & $\begin{array}{l}\text { AM-R } \\
\text { CF-I } \\
\text { CZ-I }\end{array}$ & $\begin{array}{l}\text { AM-R } \\
\text { CF-I } \\
\text { CZ-I }\end{array}$ & $\begin{array}{l}\text { AM-R } \\
\text { CF-I }\end{array}$ & $\begin{array}{l}\text { AM-S } \\
\text { CF-I }\end{array}$ & $\begin{array}{l}\text { AM-I } \\
\text { CF-I }\end{array}$ & $\begin{array}{l}\text { AM-I } \\
\text { CF-I }\end{array}$ & $\begin{array}{c}\text { AM-R } \\
\text { CF-I } \\
\text { CZ-I }\end{array}$ & $\begin{array}{l}\text { AM-R } \\
\text { CF-I }\end{array}$ \\
\hline -2 수족관 & $\begin{array}{l}\text { AM-R } \\
\text { CF-I }\end{array}$ & $\begin{array}{l}\text { AM-R } \\
\text { CF-I }\end{array}$ & $\begin{array}{l}\text { AM-R } \\
\text { CF-I }\end{array}$ & $\begin{array}{c}\text { AM-R } \\
\text { CF-I }\end{array}$ & $\begin{array}{c}\text { AM-I } \\
\text { CF-I } \\
\text { FOX-I }\end{array}$ & $\begin{array}{l}\text { AM-I } \\
\text { CF-I }\end{array}$ & $\begin{array}{l}\text { AM-I } \\
\text { CF-I }\end{array}$ & $\begin{array}{l}\text { AM-I } \\
\text { CF-I } \\
\text { CZ-I }\end{array}$ & $\begin{array}{l}\text { AM-I } \\
\text { CF-I }\end{array}$ & $\begin{array}{l}\text { AM-I } \\
\text { CF-I }\end{array}$ \\
\hline 일치여부 & 불일치 & 불일치 & 불일치 & 불일치 & 불일치 & 불일치 & 일치 & 불일치 & 불일치 & 불일치 \\
\hline
\end{tabular}

\section{2) 도심지역 횟집}

도심지역에서 분리된 Vibrio parahaemolyticus 균주 중 임의 선정한 13 건에 대한 17 종의 항생제에 대한 항생제 감수성 시험 결 과 AN, SAM, CTT, CTX, FOX, CIP, C, GM, IPM, NA, TE, TIC,
$\mathrm{SXT}, \mathrm{AMC}$ 등 14 종의 항생제에 대해서는 내성이 관찰되지 않았으 며, $\mathrm{AM}$ 은 11 건이 내성, 2건이 중간내성으로 대부분의 균이 내성을 나타냄을 알 수 있었다. 또한 $\mathrm{CF}$ 는 13건 모두가 중간내성, $\mathrm{CZ}$ 는 5 건이 중간 내성, 8건이 감수성을 나타내었다. 이 도심지역 수족관 
수에서 분리된 균주에 대한 내성결과는 Fig. 4 와 같이 나타났다.

이들 균주 중 특히 비교대상 해안지역 대형 활어센터의 동일업 소 수족관 및 취수관수 각 10 건의 항생제 내성 패턴을 비교해본 표 는 아래 Table 7 과 같다.

위에 살펴본 바와 같이 총 41 주의 균주에 대해 항생제감수성 검 사를 실시한 결과를 종합해보면 Ampicillin (AM)은 40주에서 중간 내성이상의 내성양상을 나타내어 $97.6 \%$ 의 내성율을 보였다. 이는 류 등(2010)의 87.3\%, 93.0\%라는 결과와 부합되어 보편적 현상으 로 사료된다. 또한 Cephalothin $(\mathrm{CF})$ 은 모든 균주가 중간내성을 나 타낸 반면, 류 등(2010)의 결과에서 $48.8 \%, 90.3 \%$ 를 나타내어 다 소간 차이를 보였다. 분리균주들의 항생제 내성은 육지 혹은 연안 으로부터 유입되는 다량의 항생제로 인해 자연계에서 획득하게 되 었거나, 항생제에 대해 이미 내성을 갖고 있는 균주들이 보유하고 있는 플라스미드나 해수에 존재하는 장염비브리오 특이적인 박테 리아파아지 등의 $\mathrm{DNA}$ 를 수평적인 전이를 통해 획득하게 되었기 때문인 것으로 추정할 수 있겠다(질병관리본부, 2008).

본 항생제 감수성 결과를 살펴보면 장염 비브리오균은 항생제에 대한 내성이 많이 남아있는 것으로 보이며, 이는 식중독을 일으키
는 다른 장내세균들과는 달리 자연계에서 존재하는 균들로 항생제 에 노출된 경우가 많이 없었던 것으로 파악되지만 과거 Ampicilli (AM)이나 Cephalothin $(\mathrm{CF})$ 의 과다 사용이 자연계에도 많은 영향 을 끼친 것으로 사료 되며, 무분별한 항생제의 사용과 더불어 의약 품의 지정된 방식에 따른 폐기 등 생태계에 미치는 영향도 고려해 야 할 것으로 사료된다.

\section{3. 혈청형 시험}

비교대상 수족관 및 취수관 분리균주 20건에 대해 O 1 11 항혈 청형 구분 시험 결과는 아래 Table 8에 나타내었다. 3 번 혈청에 응 집을 일으킨 균주가 8건으로 가장 많았다. K Poly 항원 I IX에 대 해서 응집반응을 일으킨 균주는 총 5균주로, 혈청형을 구분할 수 없 는 UT (untypeable) K-group이 15균주로 75\%를 나타내었으며, 이는 $69.7 \%$ 를 나타내었다는 선행연구자의 연구결과와 거의 일치 하였다(김와 조, 2002).

이중에서도 $\mathrm{K} 12$ 가 2균주, $\mathrm{K} 30$ 이 1균주, $\mathrm{K} 36$ 이 1균주, K 5 가 1 균주 등이었으며, 자갈치어시장에서 10월 2차 채수 시 분리된 두 균주가 $\mathrm{O} 4: \mathrm{K} 12$ 로 나타났으며, 이 단일혈청형에 의한 식중독 은 멕

Table 8. Antigenic Formulas of the same time isolated strains in coastal areas

\begin{tabular}{cccccccccccccccccccccccc}
\hline 혈청종류 & 균주번호 & $1-1$ & $1-2$ & $2-1$ & $2-2$ & $3-1$ & $3-2$ & $4-1$ & $4-2$ & $5-1$ & $5-2$ & $6-1$ & $6-2$ & $7-1$ & $7-2$ & $8-1$ & $8-2$ & $9-1$ & $9-2$ & $10-1$ & $10-2$ \\
\hline O 혈청형 & O4 & O4 & O11 & O3 & O5 & O3 & O10 & O3 & O3 & O6 & O2 & O3 & O1 & 01 & 011 & 05 & 03 & O3 & O3 & 010 \\
K 혈청형 & K12 & K12 & UT & UT & UT & UT & UT & UT & UT & UT & UT & K30 & UT & UT & K36 & UT & UT & K15 & UT & UT \\
\hline
\end{tabular}

M 1-2 1-2 2-1 2-2 M 3-1 9-2 L-1 4-2 M 5-1 5-2 M

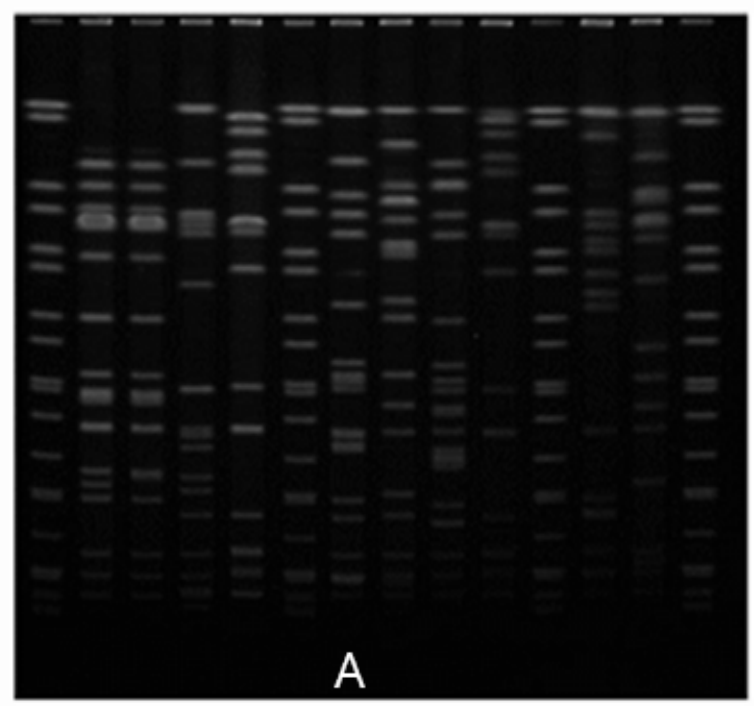

M B-1 8-2 7-1 7-2 M 8-1 8-2 9-1 9-2 M 10-1 10-2 M

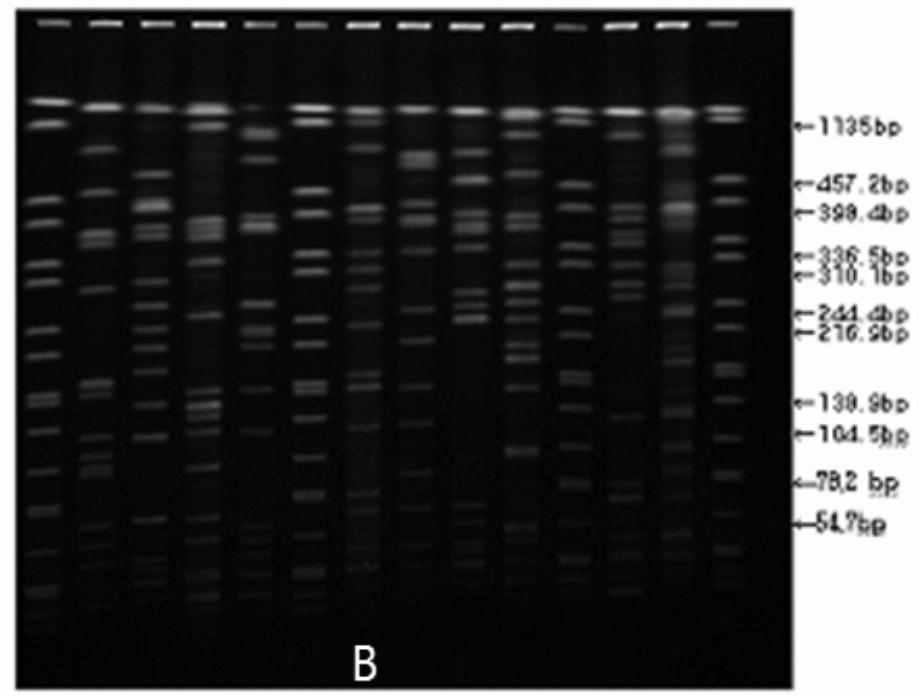

Fig. 5. PFGE patterns of Vibrio parahaemolyticus. strains isoluted from aquarium warter, intake-pipe warter on each 10 pair (A, B). 
시코와 미국 서부 해안에서 발생한 경우가 있다(Nasu 등, 2000).

\section{4. 분리균주의 PFGE 패턴 분석}

2011년 Vibrio parahaemolyticus가 취수관수 및 수족관수에 서 동시에 분리된 업소 열 군데에서 분리된 균주에 대해 PFGE를 실 시하여 수족관수에서 분리되는 균주와 취수관 오염의 연관성을 파 악하고자 하였다. PFGE 분석대상은 Table 4의 10월, 11 월 동시에 Vibrio parahaemolyticus 가 분리된 곳으로 한정하였다.

20 건의 PFGE를 분석한 결과 사진은 아래 Fig. 5 와 같다.

PFGE 결과 사진을 비교 해볼 때 이 들 1 번의 취수관 및 수족관에 서 분리된 균주가 비슷한 유전자형을 지니며, 그 외의 비교 균주들 의 유전자형은 차이가 있음을 알 수 있다. 이 PFGE 결과를 BioNumerics software (Applied Maths, Belgium)를 이용하여 Dendrogram을 작성하여 균주간의 유연관계를 비교 분석한 결과 는 Fig. 6과 같다. PFGE 결과 각 유형 간 유사도는 96.78 60.41\% 범위로 나타났다.

취수관 및 수족관의 상호 연관성을 나타내는 균주는 1 번의 자갈 치어시장에서 10월 2차 채수 시 분리된 균주 한 쌍(1-1,1-2)으로 $96.8 \%$ 의 유사도를 나타내었고, 뜻밖에 5 번과 10 번의 취수관에서
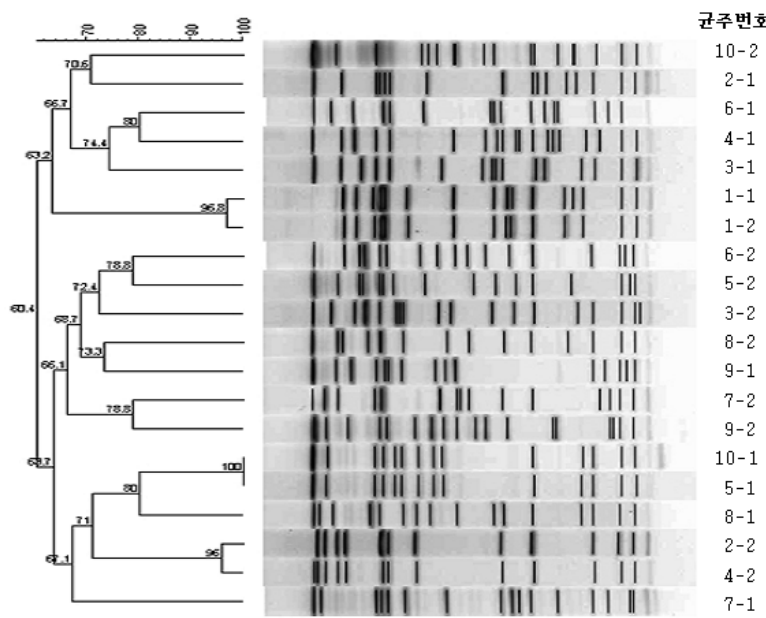

Fig. 6. PFGE Dendrogram of Vibrio parahaemolyticus. strains isoluted from aquarium warter, intake-pipe warter on each 10 pair.
분리된 균주가 $100 \%$ 의 유사도를 나타내었는데 이는 11 월에 1,2 차에 대변항 연화리에서 분리된 것으로 채수시기가 다름에도 동일 유래 균주가 분리되었다.이외의 18 건의 균주는 모두 다른 유형을 나타내었으며, 본 실험에서 분리된 19개의 유형은 국내 Pulse-net Data 분석결과와 비교하여서도 처음 확인된 유형들이었다.

한편, 항생제 감수성 시험에서는 7번 분리균주가 유사한 패턴 을, 혈청형 시험에서는 1 번 균주가, PFGE 유전자형 분석 에서 1 번 균주가 각각 유사성을 나타내어, 이들 결과를 토대로 볼 때 취수관 을 통해 유입되는 물이 수족관수에 직접적이고 가장 주요한 오염원 이 아닌 것으로 보인다.

\section{고 찰}

부산시내에 횟집, 조개구이집, 일식집 등 수족관을 보유하고 있 는 업소는 총 2,129개소로 그 구 ·군별 현황은 Table 9와 같다.

오존소독, 자외선소독, 정수기 부착 등의 방법은 위의 방법들과 비교할 때 상대적으로 위생적인 방법으로 볼 수 있겠다.

부산시 보건위생과와 각 구 ·군의 협조를 얻어 구 · 군별 2 개 업 소를 선정한 후 5 차에 걸쳐 수족관수를 채수하여 미생물검사를 실 시한 결과 위에 기술한 것처럼 총 160 건에서 비브리오균속 88 건 (비브리오 콜레라(non O-1) 1건, 비브리오 패혈증균 10건, 장염 비 브리오균 77건)이 었고, 세균수는 수족관수 기준치인 $100,000 / \mathrm{mL}$ 이상인 경우가 4건 이였으며, 대장균군은 4건에서 기준치인 1,000 이하/100 mL를 초과하는 것으로 나타났다. 전체 조사대상 160 개 업소 중 대부분의 수족관 보유 업소가 식품공전 규격에 맞는 관리 를 하고 있는 것으로 볼 수 있다. 하지만 여전히 여름철 비브리오에 의한 식중독이 전체 발생의 대다수를 차지하고 있는 현실에서 비브 리오 검출건수가 88 건으로 전체의 $55 \%$ 를 차지하고 있는 것은 위생 적인 측면에서 볼 때 그 관리방안이 절실히 요구 된다고 하겠다. 본 연구에서 도심지역 횟집 수족관수 연구 조사대상 32 개소에 대한 설문 시 나타난 다양한 청소(소독)방법에도 불구하고 5 차에 걸친 검사에서 비브리오가 한 건도 검출되지 않은 청소(소독)방법은 없 었다. 하지만, 오존소독, 자외선소독, 정수기 부착 등의 방법은 비 브리오균 이외의 식품공전 위생항목(세균수, 대장균군)에서 기준

Table 9. Aquarium installation property status in Busan metropolitan city

\begin{tabular}{ccccccccc}
\hline 중구 & 서구 & 동구 & 영도구 & 부산진구 & 동래구 & 남구 & 북구 \\
\hline 95 & 53 & 56 & 44 & 186 & 204 & 77 & 144 \\
\hline 해운대구 & 사하구 & 금정구 & 강서구 & 연제구 & 수영구 & 사상구 & 기장군 \\
\hline 268 & 186 & 70 & 76 & 116 & 212 & 102 & 240 \\
\hline
\end{tabular}

※부산광역시 보건위생과 협조자료. 
에 적합하여 상대적으로 위생적인 방법으로 볼 수 있겠다.

따라서 수족관수의 교체나 염소소독을 포함한 약품소독 등 일시 적인 정화방법도 중요하지만 수족관수에 지속적인 영향을 줄수 있 는 정수나 필터, 오존살균, UV 살균 등의 방법을 활용하는 것이 바 람직할 것으로 보인다. 아래에 요즘 많이 도입하고 있는 오존살균 및 자외선 살균법에 대해 알아보았다.

먼저 오존살균의 원리를 살펴보면, 오존은 공기 중의 산소가 번 개나 태양광선 자외선과 반응하여 자연적으로 생성되거나 고전압 하에서 전기적인 힘으로도 생성이 가능한 물질로 산소원자 세 개가 결합한 형태로 산소의 동소체이며 강력한 산화력을 가진다. 이 강 력한 산화력은 미생물의 세포막을 공격, 파괴하여 세포투과율을 변 화시켜 효소와 핵산을 불활성화 시키고 미생물을 사멸시키는 기작 을 가진다. 또한, 불안정한 상태의 고에너지 분자로 상온의 수중에 서 반감기가 짧아 자연적으로 산소로 분해되므로 잔존에 대한 우려 가 없고 처리가 용이한 장점을 가지고 있으며, 다른 살균 소독장치 에 비해 설치가 간단하고 비용이 저렴하여 수요가 점점 증가하는 추세이다. 미국에서는 오존사용규정이 1982년 GRAS (Genarally Recongnized As Safe)로 지정되었고, 일본에서는 1998년 후생성 의 제 56호 후생성 생활위생국장 통지 식품위생법에 근거하여 식 품첨가물로 등재되어 농 - 수산가공품, 야채 등의 살균과 기타 식품 가공공장내의 살균 등에 사용되고 있으며, 농도의 제한 없이 사용 이 가능하다(Tenover 등, 1955). $0.2 \mathrm{ppm}$ 이상의 오존수에서 병원 성 미생물 살균효과가 나타나며, 오존수가 수돗물보다 높은 미생물 감소효과를 나타내며, 농도가 증가할수록 미생물 감소효과가 증가 하여 농도 의존적이다, $0.2 \mathrm{ppm}$ 의 저농도 오존수 처리 시에도 미생 물 제어효과를 나타내어 오존수가 식품안전성의 향상에 사용이 가 능하다(박와 신, 2010).

그러나 오존의 경우 고농도 발생 시 활어에 치명적인 약점이 있 다.

오존은 강력한 살균작용이 있는 반면 인체나 어체에 대하여 독 성을 나타내기 때문에 폭기 혹은 활성탄 처리 등으로 오존 혹은 오 존과의 반응물질을 제거한 용수로 사용하여야 할 필요가 있다. 해 수 중에는 브롬 등 여러 종류의 미량성분이 존재하여 이러한 성분 과 반응한 오존은 Oxidant로 생성되어 비교적 장시간 수중에 잔류 할 수 있으며, 수중에 잔류농도가 $0.03 \mathrm{ppm}$ 이상일 경우 어독성을 가진다는 보고가 있다(오와 조, 2001). 일반적인 어류 병원미생물 및 병원바이러스의 불활성화를 위해 요구되는 오존처리 해수의 잔 류옥시단트 농도 및 처리시간은 수중 옥시단트 농도가 $0.1 \mathrm{ppm}$ 을 유지할 경우 5 분의 반응시간, $0.3 \mathrm{ppm}$ 일 경우도 5 분, $0.5 \mathrm{ppm}$ 은 3 분의 반응조건이 성립되어야 한다. 문헌에 따르면 수조와 오존처 리조를 분리하고 오존처리조의 잔 옥시단트 농도를 $0.3 \mathrm{ppm}$ 으로
하고 조정한 후 활성탄 반응 후 수족관내 유입수의 잔류오존 측정 결과 0 0.02 ppm을 유지하였고, 어류에 이상을 초래할 만큼의 잔류량은 없었다. 하지만 장기간의 농도별 독성은 확인할 필요가 있을 것으로 나타났다(오와 조, 2001).

오존살균과 비교하여 자외선(UV)살균의 경우 비교적 간단한 설 비로 살균목적을 달성할 수 있어 최근 들어 주목받기 시작했다. 이 러한 UV살균은 단독으로 사용하여 살균목적을 달성하기도 하지만 다른 공정과 Hybrid 공정을 이루어 복합적으로 사용되기도 한다. 일례로 광화학 촉매제로써 자외선을 이용하여 산화력이 강한 $\mathrm{OH}$ Radical에 의한 살균 처리기술이 각광받고 있다.

자외선은 세포의 유전정보를 갖는 유전자인 핵산의 DNA를 손 상시키는 것에 의해 살균력을 발휘한다. 자외선은 핵산(DNA, $\mathrm{RNA})$ 의 불포화 결합에 작용하는 것으로 알려졌는데 핵산이 작는 복제능력을 잃게 하여 생물의 불환성화를 초래하는 것이다. 자외선 살균의 특이한 점은 다른 살균제에서는 볼 수 없는 살균에 대한 영 향인자로서 자외선 살균효과가 빛에 의해 감소하는 현상이 있다. 이른바 광회복(Photoreactivation)으로 이는 자외선에 의해 불활 성화된 세균이 가시광선조사에 의해 회복되는 것이다. 이러한 현상 은 자외선살균의 기본적 메커니즘이 파괴가 아니고 미생물의 불활 성화인 것에 초래한다. 이를 방지하려면 충분한 자외선조사가 이루 어져야하며 이러한 것은 초기투자와 유지관리비에 영향을 미친다. 또한 자외선은 잔류살균력이 전혀 없다. 자외선의 살균효과는 자외 선 파장 중에서도 주로 $200 \mathrm{~nm}$ 에서 $280 \mathrm{~nm}$ 사이의 UV-C영역에 서 발생하며 UV-C는 살균(Germicidal)선이라고 하며 DNA와 단 백질 그리고 오존이 잘 흡수하는 파장이다. 따라서 오존을 잘 분해 하기 때문에 최근에는 UV/Ozone 고도처리공정에 응용되거나 오 존파괴용 그리고 살균용으로 사용되고 있다.

살균용 자외선 에너지 발생장치로 주로 사용하는 것은 저압수은 램프이다. 수은램프는 살균효과가 가장 높은 적정한 범위(250 $270 \mathrm{~nm}$ )내의 파장인 $253.7 \mathrm{~nm}$ 에서 85\%정도의 광선출력을 내기 때문에 주로 사용되고 있다. 대부분 수은-아르곤 램프가 이용된다 (장와 김, 2005).

수온이 $20 \sim 25^{\circ} \mathrm{C}$ 인 수조 내에 활어를 키우면서 자외선 $30 \mathrm{w}$ 조 사 시 해수와 활어의 표피에 있는 세균은 시간이 지날수록 점차적 으로 감소하는 경향을 보였으나, 내장의 균수는 30 일만에 $0.5 \mathrm{log}$ cycle 감소한 후에 시간에 지날수록 비슷한 균수를 유지하였다. 또 한 수온을 $15,20,20^{\circ} \mathrm{C}$ 로 정하여 자외선을 $30 \mathrm{w}$ 조사할 경우 수온 이 낮을수록 제균효율은 높아져서 $15^{\circ} \mathrm{C}$ 일 때 15 일 동안 조사시 해 수, 활어의 표피, 내장의 세균은 $2 \log$ cycle 이상이 감소되었고, 수 온이 높을수록 제균효율은 낮은 것으로 나타났다. 하지만, 자외선 을 조사하다가 중단하면 순환수조 내에서 곧바로 비브리오균이 증 
식된다. 이러한 단점에도 불구하고, 자외선조사의 경우 전력 소비 면에서 경제적일 뿐만 아니라 안전하고 제균력이 $90 \%$ 이상을 보여 활용가치가 매우 높으며 생선회에서 유래한 식중독 사고를 예방하 기 위해서는 수온을 $15^{\circ} \mathrm{C}$ 이하로 유지하며 도마나 칼 등으로부터 의 이차오염방지가 필수라고 하겠다(장동석 등, 1998).

오존살균이나 자외선살균 등 일시적이지 않고 살균, 자외선 살 균 등 수족관수를 지속적으로 관리할 수 있는 살균시스템의 도입은 수족관의 위생관리는 물론 식중독예방을 위한 필수적인 과제라 하 겠으며, 일부 일식집 등에서 활용하는 활어를 바로 먹는 식습관이 아닌 활어를 장만한 후 일정시간 냉장한 후 먹는 방식으로의 기호 변화도 위생측면에서 고려해야 할 식습관으로 사료되며, 지속적인 홍보나 계도를 통해 위생적이고 안전한 먹거리 문화 정착에 힘써나 감이 마땅할 것이다.

\section{참고문헌}

Ching, K. S.,"The genetic corralation among Setotypes and PFGE patterns of Streptococcus pneumoniae isolated in Korea", Korean Society of Environmental Health, 2004, 30(1):15 21.

De Lappe, N., Dorna, G., Comnor, J.O., Mamina, C. and Cormican, M., "Use of pulsed-field gel electrophoresis of comparison of similar but distinuishable isolates of Shigellasonei collected in Ireland and Italy", Journal of Clinical Microbiology, 2006, 44(10):3808 3810.

Gupta, A., Swarnkar, N.K., and Choudhary, S.P. Changing antibiotic sensitivity in enteric fever. J. Trop. Pediatr. 2001, 47:369-371.

Hakanen, A., Kotilainen. P., Huovinene, P., Helenius, H., and Siitone, A..Reduced fluoroquinolone susceptibility in Salmonella enterica serotypes in travelers returning from Southeast Asia. Emerg. Infect. Dis. 2001, 7:996-1003.

Isenbarger, D.W., Hoge, C.W., Srijan, A., Pitarangsi, C., Vithayasai, N., Bodhidatta, L., et al. Comparative antibiotic resistance of diarrheal pathogens from Vietnam and Thailand, 1996-1999. Emerg. Infect. Dis. 2002, 8:175-180.

Kim, S.H., Lee, S.W., Kim, S. H., Kim, J. Y., Lee, H. Y., kang, Y.H., et al. National Early Warning System Construction for Timely
Surveillance of Food-borne Diseases, Center For Infection, Center for Infectious Diseases, National Institute of Health, Seoul, Korea, Infection and Chemotherapy, 2006, 38(6):309 315.

Matsumoto, C., Okuda, J., Ishibashi,, M. Iwanaga, M., Garg, P., Rammamuthy, T., et al. "Pandemic spread of an O3:K6 clone of Vibrio parahaemolyticus and emergence of related strains evidenced by arvitrary primed PCR and TOXRS sequence analyses. Jurnal Clinical Microbiology, 2000, 38:578-585.

Nasu H., India, T.Sugahara, Y. Yamaguchi, K.S. Park, K. Yokohama, et al. "A filamentous phage associated with recent pademic Vibrio parahaemolyticus O3:K6 strains", J. Clin. Microbiol. 2000, 38: 2156 2161.

Tenover FC, Arbeit RD, Goering RV, Mickelsen PA, Murray BE, Persing $\mathrm{DH}$, et al. : Interpreting chromosomal DNA restriction patterns produced by pulsed -field gel electrophoresis : criteria for bacterial strain typing. J Clin Microbiol 1995, 33(9):2233-2239, 1995.

김영록, 조성환. Vibrio parahaemolyticus에 대한 황금추출물의 항균 활성. 한국식품영양과학회지. 2002, 31;534-538.

류승희, 황영옥, 박석기, 이영기. 시판 어패류에서 분리한장염 비브리오균의 항생제 감수성 특성. 한국식품과학회지. 2010, 42;508-512.

박정미, 신한승. 오존수와 오존수를 이용한 세척방법이 식중독 세균 제어에 미치는 영향. 한국산업식품공학회. 2010, 14; 316-321.

방선재, 박광희, 박명기, 권연옥, 고환욱. Salmonella othmarschen에 의한 집단식중독사례의 분자역학적 분석. 한국환경보건학회지. 2008, 34; 170-174.

설성용, 장경수, 정웅기, 조웅래, 김능희, 유학선 등. 병원재료에서 분리한 Stenotrophomanas maltophilia의 항균제 내성 및 분자역학적 특성. $J$ Korean Soc Microbiol. 2000, 35; 239-240.

식품의약품안전청. 항생제 내성균 검사 표준 시험법. 2010, p133-137.

오명주, 조현서. 오존처리에 따른 해수중 어류 병원체의 관리. 한국양식학회 지. 2001, 13;17-23.

이복권, 김성한, 김준영, 이경신, 전세미, 추윤애. PFGE(Pulsed Field Gel Electrophoresis) 표준실험법, 질병관리본부, 2008, 1-32.

이향, 오영희, 최성민, 박석기. 어패류에서 분리한 장염비브리오균의 분포 및 항균제감수성. 한국환경보건학회지. 2007, 33;16-20.

장동석, 임성미, 이은우, 유홍식. 자외선 조사선량과 수온에 따른 병원성 비브 리오균의 변화. 한국보건교육-건강증진학회지. 1998, p220.

장인성, 김준영. 자외선을 이용한수(水)처리 살균기술. 조명·전기설비학회 지. 2005, 19;14-21.

질병관리본부. 감염병 실험실진단 I 질환별 시험법, 2005, p25.

질병관리본부. “항균제 감수성 표준시험법”, 2008. 110 116. 